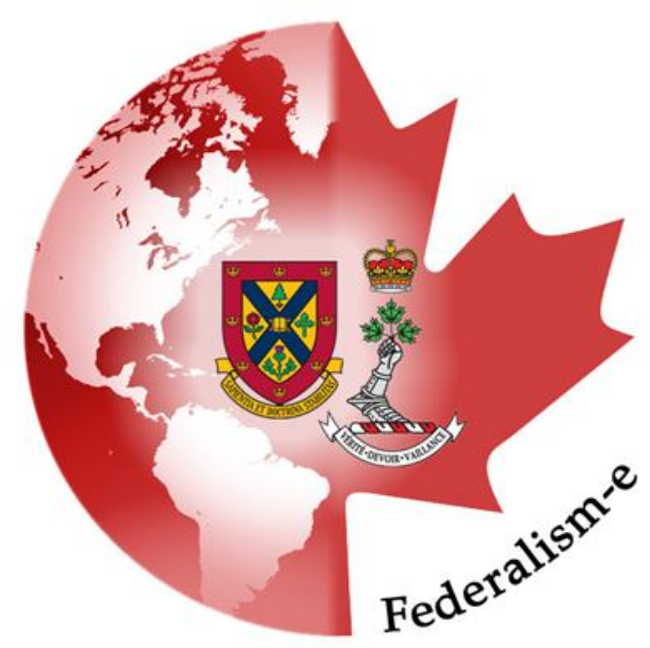

\title{
The Return of Federalism and Constitutional Politics: Analyzing the Role of the Supreme Court as an Arbiter in Contemporary Political Society
}

\section{MARJUN PARCASIO \\ University of Ottawa}

Since the ascendancy of the Charter of Rights and Freedoms as the centrepiece of a new constitutional order in Canada, there has been a distinctive decline of federal discourse in the courts and within the political sphere. Traditional cases pertaining to the division of powers at the Supreme Court have been eclipsed by the novelty of rights jurisprudence that has consumed the court in the past three decades ${ }^{1}$. Moreover, constitutional issues have been considered an anathema since the failure of the negotiations at Meech Lake and Charlottetown, exacerbated by the near-death experience for federalism in the 1995 referendum in Québec. In recent years, however, the changing nature of Canada's political dynamics has signalled a return of federalism and constitutional politics. The

\footnotetext{
${ }^{1}$ Wayne MacKay, "The Supreme Court of Canada and Federalism - Does \Should Anyone Care Anymore," Canadian Bar Review 80 (2011), p. 243.
}

Supreme Court enshrined federalism as one of the four principal tenants of the Canadian constitution, arguing in its Reference re Secession of Quebec that federalism is "a legal response to the underlying political and cultural realities that existed at Confederation and continue to exist today" ${ }^{2}$. With these realities changing in the face of new leadership and evolving environments, this essay will examine how and to what extent the judicial branch shapes Canada's distinct federal dynamics and assess its relationship with political actors in the twenty-first century.

We will examine this question in a tripartite manner, beginning firstly with an overview of the legal principles and academic literature pertaining to federalism. The court's jurisprudence and key doctrines regarding the constitutional division of powers since

\footnotetext{
${ }^{2}$ Reference re Secession of Quebec [1998] 2 S.C.R. 217, s. 32.
} 
Confederation will be briefly examined ${ }^{3}$, along with the theoretical foundations of federalism within the political science literature. In this manner, the relevant case law and academic work can be used to situate and comparatively analyze the contemporary era with its historical development. But given the broad nature of federalism studies in political science, our methodological approach throughout this paper will necessarily be limited to federalism as it has manifested itself in the courts, paying particular focus on the issues faced by the McLachlin court since the Conservative Party of Canada came into power in 2006. In so doing, this paper hopes to offer innovative reflections on the government's position on federalism vis-à-vis the Supreme Court, using recent developments in a relatively unexplored subdomain within the field.

The second section will begin the substantive matter of our discussions. The Conservative Party since its election victory in 2006 has touted a vision of "open federalism" to guide federal-provincial relations, a purported change to Canada's federal order ${ }^{4}$. This approach, which conforms to classical federal theory, aims to re-establish a commitment towards the classical model of 'watertight compartments' for federal and provincial jurisdiction ${ }^{5}$. However, an analysis of case law and examples such as the decision on the national securities regulator $^{6}$ and the landmark Insite judgment ${ }^{7}$ suggests that the

${ }^{3}$ Patrick Monahan, Constitutional Law, $3^{\text {rd }}$ ed. (Toronto: Irwin Law, 2006), p. 230-252.

${ }^{4}$ Prime Minister of Canada, "Prime Minister promotes open federalism," Apr. 21, 2006, http://pm.gc.ca/eng/media.asp?id=1123.

${ }^{5}$ Peter C. Oliver, "The Busy Harbours of Canadian Federalism: The Division of Powers and Its Doctrines in the McLachlin Court," Public Law at the McLachlin Court: The First Decade, eds. David A. Wright and Adam M. Dodek, (Toronto: Irwin Law, 2011), p. 172.

${ }^{6}$ Reference re Securities Act, [2011] SCC 66.

${ }^{7}$ Canada (Attorney General) v. PHS Community Services Society, 2011 SCC 44, [2011] 3 S.C.R. 134. federal government's idyllic notion of federalism is more a product of political posturing than a normative governing philosophy. It will be argued that this approach signals a move towards greater unilateralism on the part of the federal government whilst exacerbating tensions amongst Canada's regions, thus undoubtedly involving the Supreme Court as a regulator and facilitator amongst the different units of the federation. The Supreme Court, as a result, has remained consistent in the face of ambivalent political positions and places itself as an actor promoting cooperation, compromise, and discussion between the federal and subnational governments of Canada's federation.

The final section will conclude with an analysis of the Supreme Court's place within Canada's institutional framework. Emerging contestations will undoubtedly place the court in a fragile position. With the political attention garnered by Bills $\mathrm{C}-7^{8}, \mathrm{C}-10^{9}$, and $\mathrm{C}-19^{10}$, all of which have been contested by several provinces with impending legal action, it will be the task of the courts to adjudicate between highly conflicted and sensitive positions. The divisive nature of the government's legislative agenda is further indication of its inconsistency and the threat it poses to national unity. More importantly, these conflicts are cogent reminders that the legacy of federal problems in Canadian history have not disappeared and that the Supreme Court's role in balancing the elements of the constitution remains a

\footnotetext{
${ }^{8}$ Bill C-7, An Act respecting the selection of senators and amending the Constitution Act, 1867, in respect of Senate term limits, $1^{\text {st }}$ session, $41^{\text {st }}$ Parliament, 2011.

${ }^{9}$ Bill C-10, An Act to enact the Justice for Victims of Terrorism Act and to amend the State Immunity Act, the Criminal Code, the Controlled Drugs and Substances Act, the Corrections and Conditional Release Act, the Youth Criminal Justice Act, the Immigration and Refugee Protection Act and other Acts, $1^{\text {st }}$ session, $41^{\text {st }}$ Parliament, 2011.

${ }^{10}$ Bill C-19, An Act to Amend the Criminal Code and Firearms Act, $1^{\text {st }}$ session, $41^{\text {st }}$ Parliament, 2011.
} 
fundamental component of Canada's system of federal governance.

This role, while welcomed, has limitations. The necessity for judicial independence and the importance of a neutral arbiter is threatened with an increasingly active Supreme Court, particularly in areas of extensive political debate ${ }^{11}$. The Supreme Court must therefore play an enabling role in federalprovincial conflicts, acting in a meta-political role in its decision-making process through the promotion of a vision of federalism that calls for collaboration amongst Canada's federal entities ${ }^{12}$. However, it must be understood that the decisions on the future of federalism and the direction it will unfold in the future is not wholly decided by the Supreme Court. This paper, in highlighting the importance of the Supreme Court in federalism, is qualified by an understanding that the court is surrounded by a divisive political arena which generates the inputs for eventual litigation. It is therefore political actors, in expressing their political will, who must ultimately provide a vision for federalism in Canada, with the Supreme Court providing the necessary guidance to ensure that this vision conforms to the limits prescribed by constitutional law.

\section{Historical and Legal Foundations for Federalism: The Case of Canada}

Federalism in Canada has operated upon a number of principles, and shaped by over a century of court jurisprudence that is deeply rooted within Canada's history. The Honourable Senator Nolin describes the foundations of Canadian federalism as a result

\footnotetext{
${ }^{11}$ Shannon Ishiyama Smithey, "The Effects of the Canadian Supreme Court's Charter Interpretation on Regional and Intergovernmental Tensions in Canada," Publius 26:2 (1996), p. 83.

12 James B. Kelly and Michael Murphy, "Shaping the Constitutional Dialogue on Federalism: Canada's Supreme Court as Meta-Political Actor," Publius 35:2 (2005), p. 218.
}

of a wide set of factors that necessitated political union within British North America in 1867:

Au milieu du XIXe siècle, la fin anticipée du Traité de Réciprocité entre les colonies britanniques d'Amérique du Nord et les États-Unis d'Amérique, doublé de la fin des tarifs préférentiels avec la métropole britannique, il devenait de plus en plus nécessaire pour ces colonies de s'unir dans un État, entre autres pour des raisons économiques. La négociation, qui aboutirait à la création du Canada, déboucha sur un compromis politique provoqué par les oppositions tant démographiques, que géographiques, religieuses et linguistiques, des participants. ${ }^{13}$

We can determine that the federal compact, at its core, was underpinned by an implicit acknowledgment of diversity within the federation and the need to preserve the character of its governing entities. It is from this agreement that the British North America Act of 1867 was forged $^{14}$, and with it, the allocation of powers between the two levels of government and the creation of a judicial system of appeals, both of which feature prominently in our modern discussion on federalism.

The Canadian constitution thus specified the powers allocated between the provincial and federal governments within sections 91 and 92 of the $\mathrm{Act}^{15}$. Despite its centralist tendencies, the constitution's attempt to exclusively regulate provincial and federal domains of jurisdiction was blissfully ignorant of the overlapping tendencies of the heads of powers and the evolution of jurisdictional boundaries that were necessitated by the

\footnotetext{
${ }^{13}$ The Honourable Pierre-Claude Nolin, interview by Marjun Parcasio, Senate of Canada, May 3, 2012.

${ }^{14}$ The Constitution Act, 1867 (UK), 30 \& 31 Victoria, c 3.

${ }^{15}$ Ibid., s. 91 and 92.
} 
document's ambiguity and open-ended nature ${ }^{16}$. Nevertheless, in its formative years, the judiciary sought to ensure the protection of provincial domains from undue federal interference. It is from the resulting jurisprudence of the Judicial Committee of the Privy Council (JCPC), then Canada's highest court of appeal, that the notion of "watertight compartments" aimed at minimizing overlap between federal and provincial jurisdictions became prominent ${ }^{17}$. The Harper government's view in invoking this form of classical federalism not only ignores certain political realities but also diminishes the impact of the legal doctrines developed throughout the years, as we will discuss in the subsequent section.

The replacement of the JCPC by the Supreme Court as the court of last appeal in 1949 signalled a new era for Canadian federalism, both in doctrinal aspects and its overall approach. The post-war period saw the rise of cooperative federalism, with the growth of government in economic and social spheres necessitating the need for shared jurisdictions and coordination amongst the federal units ${ }^{18}$. The court also bolstered its pith and substance analysis, developing further the double aspect doctrine in recognizing that legislative actions taken by both the federal and provincial governments on the same subject can be considered valid $^{19}$. The Honourable Senator Segal describes this period as one in which:

${ }^{16}$ Patrick Monahan, Constitutional Law, p. 231.

${ }^{17}$ Ibid., p. 233. See also the decision of Canada (Attorney General) v. Ontario (Attorney General), [1937] A.C. 326, paragraph 354.

18 James Bickerton, "Deconstructing the New Federalism," Canadian Political Science Review 4:2-3 (2010), p. 57.

${ }^{19}$ Peter Oliver, “Canadian Legal Federalism since 1982" (paper presented at the Checking our Constitution@30 Conference, University of Ottawa, Ottawa, April 17-18, 2012), p. 2. The doctrine was first established in the case of Hodge v. R. (1883), 9 App. Cas. 117 (P.C.): "subjects which in one aspect and for one purpose fall within sect. 92, may in another aspect and for another purpose fall within the Supreme Court...[forced] governments at the federal or provincial level to put some water in their wine. Its decisions in the period leading up to the 1982 constitutional accord that gave us patriation of the British North America Act from the UK Parliament and the Charter of Rights essentially told both levels of government that they needed to work together, and neither level could block or proceed unilaterally. ${ }^{20}$

In the face of the executive federalism of the 1970 s and 1980s, however, it was evident that the federal government nevertheless continued to exercise a substantial degree of influence in the operation of the federation. The literature describes this period as one in which the "Supreme Court demonstrated a consistent centralist stance" ${ }^{21}$. The court's formative development as an independent body and its establishment of over a century of legal jurisprudence are important considerations to retain as we examine what scholars call the modern era of the Supreme Court.

As alluded to earlier, the Charter of Rights and Freedoms did much to change the direction of the court from a substantial focus on the division of powers to the need to develop a new regime of rights jurisprudence. To this end, the court aimed at "stabilizing and clarifying legal federalism and of reducing the volume of litigation" 22 ; this was achieved in a

sect. 91." However, a detailed analysis of legal doctrine and analysis falls outside the scope of this paper. Further details can be found in Monahan's Constitutional Law or Oliver's "The Busy Harbours of Canadian Federalism: The Division of Powers and Its Doctrines in the McLachlin Court."

${ }^{20}$ The Honourable Hugh Segal, interview by Marjun Parcasio, Senate of Canada, May 1, 2012.

${ }^{21}$ André Bzedra, "Comparative Analysis of Federal High Courts: A Political Theory of Judicial Review," Canadian Journal of Political Science 26 (1993), p. 5. 22 Oliver, "Canadian Legal Federalism since 1982," p. 4 
number of cases that solidified the division of powers and a number of the court's remaining legal doctrines. In the case of General Motors of Canada Ltd. v. City National Leasing, the Supreme Court established the criteria for acts taken under the trade and commerce power in section 91(2), thereby contributing to further codification of the heads of powers determined by the constitution ${ }^{23}$. Moreover, in the Multiple Access case, the paramountcy provision in the constitution, which deemed the federal law to be paramount to its provincial counterpart in areas of conflict, became institutionalized in a test that limited its application ${ }^{24}$. The importance of these cases and various doctrines must be highlighted, for they consist of the landmark decisions that have helped shape the reaction of the McLachlin court in response to the agenda of the Conservative government in recent years. Legal federalism, it seems, became the subtle background to a country preoccupied with protecting individual rights and exhausted by the constitutional debacles of the 1980 s and 1990s.

It is with this history in mind that we turn to the twenty-first century, particularly the court under Chief Justice Beverly McLachlin, to ascertain how legal federalism has shifted and what challenges it has faced and will face in the future. We must remain cognizant that the law and the Supreme Court do not exist in convenient vacuums easily delineated by arbitrarily-assigned boundaries of jurisdiction and scope. The Canadian judicial system is resilient, and in-keeping with the metaphor of the constitution as a "living tree," it adapts itself to the challenges posed by governments and citizens in contemporary political society ${ }^{25}$. With

${ }^{23}$ General Motors of Canada Ltd. v. City National Leasing, [1989] 1 S.C.R. 641

${ }^{24}$ Multiple Access Ltd. v. McCutcheon, [1982] 2 S.C.R. 161

${ }^{25}$ Katherine Swinton, "Federalism under Fire: The Role of the Supreme Court of Canada," Law and Contemporary Problems 55:1 (1992), p. 126. See also Reference re Same-Sex Marriage, [2004] 3 S.C.R. 698, 2004 SCC 79, Question 1: "our Constitution is a living interjurisdictional and federal-provincial conflicts becoming increasingly pronounced in Canadian politics, the eyes of the nation will fall on the Supreme Court and how it reacts to this resurgence of federalism and constitutional politics.

\section{Federalism under the Harper Conservatives: A Case of Inconsistency}

An examination of federalism under the period of Conservative rule remains a difficult task, given that we do not have the necessary distance from the events of the past six years to take advantage of historical hindsight and analysis. Nonetheless, after three elections producing consecutive Conservative governments, there is much to be said regarding the direction the government has approached federal politics. In assessing the Harper government's record on federalism, it is argued that the government's theoretical approach fails to achieve its purported aims and instead fosters discord amongst the regions. The two case studies of the national securities regulator and the Insite judgment in British Columbia will reveal, in contrast, the court's sympathy towards cooperative federalism, thereby placing the onus on the Supreme Court to bridge the gap between the presumptuous approach of unilateralism by the federal government and an increasingly vocal set of provinces asserting their constitutional rights.

The Conservatives under the leadership of Stephen Harper have been remarkably consistent on their public approach to federalism. Even prior to forming government, Harper in an editorial to the National Post argued for "renewed respect for the division of powers between the federal and provincial

tree which, by way of progressive interpretation, accommodates and addresses the realities of modern life." 
governments" 26 . This principle was reflected soon thereafter in the first platform of the Conservative Party in the 2006 election, whereby they call for the "federal government to establish a new relationship of open federalism within the provinces," while acknowledging that "preserving the country's unity is the federal government's foremost responsibility" ${ }^{27}$. In the subsequent 2008 and 2011 elections respectively, the need to "respect the jurisdiction of the provinces and territories in the Constitution Act, 1867" ${ }^{28}$ and to "work collaboratively with the provinces" 29 was duly emphasized. The concept of open federalism is one which resets the clock on federalism, bringing back the concept of watertight compartments seen under the Judicial Committee of the Privy Council. It is built on the assumption that exclusive jurisdiction between the heads of powers in sections 91 and 92 of the Constitution can be effectively maintained, and furthermore, that this form of federalism is in fact beneficial for Canadian society. Decentralization and mutual respect for constitutional mandates are the pillars upon which the Harper Conservatives proposed a different federal vision for Canada.

However, the reality of the past six years of Conservative governance has been far

\footnotetext{
${ }^{26}$ Stephen Harper, "My Plan for Open Federalism," National Post, A19, October 27, 2004, http://www.jamesmoore.org/harperpostoct27.htm.

${ }^{27}$ Conservative Party of Canada, "Stand Up for Canada: Conservative Party of Canada Federal Election Platform," 2006, p. 42,

http://www.cbc.ca/canadavotes2006/leadersparties /pdf/conservative_platform20060113.pdf.

${ }^{28}$ Conservative Party of Canada, "The True North Strong and Free: Stephen Harper's plan for Canadians," 2008, p. 26, http://www.conservative.ca/media/2008-Platforme.pdf.

${ }^{29}$ Conservative Party of Canada, "Here for Canada: Stephen Harper's Low-Tax Plan for Jobs and Growth," 2011, p. 30, http://www.conservative.ca/media/ConservativePlat form2011_ENs.pdf.
}

from the rosy picture of respected jurisdictional boundaries and mutual trust touted by the federal government. In a number of instances, the government has chosen to proceed with a legislative agenda that, despite having major repercussions on the subnational units of the federation, fails to include them within considerations. This approach "is consistent with a broader neoliberal approach to federalism which, among other aims, seeks to use institutional reforms to lock in more market-oriented public policies" ${ }^{\prime 30}$. In this sense, the call for open federalism à la Harper is one in which the government merely chooses to flex its powers, assuming that its ancillary effects on the provinces are ones which can be conveniently ignored. Open federalism is therefore a misnomer: it is closed, isolated, and fails to adequately engage with the provinces and territories of the Canadian federation.

When government ideology replaces principle, it is incumbent on the courts to ensure that the core principles which underpin the country remain steadfast. The case of the proposed national securities regulator provides one such example. The Conservative government, supported in this case by the Attorney General of Ontario, sought to consolidate the thirteen separate agencies run by provincial governments under one national regulator. Its arguments were based on the idea that the action fell under section 91(2), the trade and commerce clause of the constitution $^{31}$. It faced a slew of opposition from a number of provinces, including Alberta, Québec, Manitoba, and New Brunswick, that claimed the power fell under section 92 over property and civil rights ${ }^{32}$. The Supreme Court's decision to rule in favour of the provinces and its reasoning for doing so is a rebuff on the presumption that the government can proceed

\footnotetext{
${ }^{30}$ Adam Harmes, "The Political Economy of Open Federalism," Canadian Journal of Political Science 40:2 (2007), p. 418.

${ }^{31}$ Reference re Securities Act [2011] SCC 66, par. 4. ${ }^{32}$ Ibid.
} 
in a legislative action of this magnitude without the necessary agreement from the federation's composing members.

The court used the criteria as established in General Motors and found that the sweeping nature of the legislation would be a complete takeover of securities industry that ran contrary to the constitution, despite favourably looking upon the need for economic regulation on a national level ${ }^{33}$. It has been suggested, as a result, that the Supreme Court's decision was tantamount to a setback to national unity and to the effective use of coordination in policy, thus harming federalism in Canada ${ }^{34}$. While the economic arguments for a regulator are compelling, the court noted that:

It is a fundamental principle of federalism that both federal and provincial powers must be respected, and one power may not be used in a manner that effectively eviscerates another. Rather, federalism demands that a balance be struck, a balance that allows both the federal Parliament and the provincial legislatures to act effectively in their respective spheres. ${ }^{35}$

While considerations of political or economic expediency or efficiency may be logical reasons within the political arena, the means through which changes are achieved in the political arena must necessarily conform to the constitutional limits prescribed by law. "A

${ }^{33}$ Ibid., par. 128.

${ }^{34}$ Gord DiGiacorno, "Take-away lessons from the SCOC's decision on the Securities Act," iPolitics.ca, March 22, 2012, http://www.ipolitics.ca/2012/03/22/gord-

digiacomo-securities-act-decision-not-helpful-tocanada/. See also the response of the Canadian Banker's Association, one of the interveners in the Reference re Securities Act case at http://www.cba.ca/en/media-room/65-newsreleases/600-cba-response-to-supreme-court-ofcanada-decision-on-securities-regulation-.

${ }^{35}$ Reference re Securities Act [2011] SCC 66, par. 7. functional effectiveness approach," writes political scientist Jean Leclair, "will undermine the very values that federalism is meant to promote" ${ }^{36}$. The federal government, in blatantly proceeding without taking into account these limits, was understandably reproached by a Supreme Court where balance and dialogue continue to remain important principles to maintain Canada's operational framework.

The decision that the Securities Act was ultra vires of the Parliament's constitutional power was understandably disappointing to the federal government. However, the Supreme Court nevertheless recognized the possibility of a national scheme that would be predicated on the government taking a "cooperative approach" with its provincial counterparts ${ }^{37}$. This provision speaks to an extension of the form of cooperative federalism promoted by the Supreme Court, which has in the twentyfirst century been less expansive in its application of powers such as the trade and commerce power ${ }^{38}$. Open federalism, in its idealistic form, remains a myth: the delineation of exclusive spheres of jurisdiction is impossible in a world where globalization of markets and interconnectedness have become a norm. Ironically, the government's actions in the national securities regulator only demonstrate a lack of principled commitment to the concept in the face of neoliberal and ideological pressures.

Within the constitutional framework, however, the Supreme Court has not limited itself to the strict division of powers to protect federalism in Canada. The case of Canada (Attorney General) v. PHS Community Services

\footnotetext{
${ }^{36}$ Jean Leclair, "The Supreme Court's Understanding of Federalism: Efficiency at the Expense of Diversity," Queen's Law Journal 28 (2003), p. 411, https://papyrus.bib.umontreal.ca/jspui/handle/1866 /1431.

${ }^{37}$ Reference re Securities Act [2011] SCC 66, par. 130.

${ }^{38}$ Oliver, "Canadian Legal Federalism since 1982," p. 7.
} 
Society, known colloquially as the Insite decision, is a further case study in which the courts challenged the abrasive approach of the federal Conservatives using a full range of constitutional analyses. The decision reflects not only an application of a wide range of legal doctrines, but also serves as a reminder about the complementary role that the Charter of Rights plays in addition to the constitutional division of powers in the constitution.

The Insite facility, located in downtown Vancouver East Side, was aimed at providing a supervised injection site for drug users to minimize the health and mental risks associated with drug use. Premising their actions on moral implications and social conservatism, the Conservative government sought to shut down the facility. The Supreme Court was thus faced with two questions to determine the validity of the federal government's case on cross-appeal: whether the ability to shut down the site fell within the division of powers, as well as whether its actions were consistent with the rights in section 7 of the Charter ${ }^{39}$. The first question was considered with respect to the doctrine of interjurisdictional immunity. This doctrine, a relic of the watertight compartments direction of the court, posits that powers within either sections 91 or 92 consist of a core element that is immune from the effects of legislation based in the other set of powers $^{40}$. However, the McLachlin court in its previous decision in Canadian West Bank had already downgraded the doctrine's application

\footnotetext{
${ }^{39}$ Canada (Attorney General) v. PHS Community Services Society, 2011 SCC 44, [2011] 3 S.C.R., par. 36.

${ }^{40}$ Oliver, "The Busy Harbours of Canadian

Federalism: The Division of Powers and Its Doctrines in the McLachlin Court," p. 171. Further elaboration on the intricacies of the interjurisdictional immunity doctrine and its evolution can be found in Oliver, “Canadian Legal Federalism since 1982," p. 4 and Monahan, Constitutional Law, p. 120-126.
}

and thus its relevance in the modern age ${ }^{41}$. The Supreme Court, when considering the applicability of interjurisdictional immunity for Insite, submitted that its "premise of fixed watertight cores is in tension with the evolution of Canadian constitutional interpretation towards the more flexible concepts of double aspect and cooperative federalism" ${ }^{42}$. Paradoxically, while the doctrine was used in an attempt to maintain the Insite facility, the court's reasoning illuminates further an approach that stresses the need for cooperation rather than seclusion when it comes to the division of powers. Moreover, the government's attempt to shut down Insite based on an ideological position rather than the scientific evidence betrays its supposed commitment to open federalism and a respect for provincial matters of jurisdiction.

The second question before the court regarding the Charter was answered in the negative. To eliminate the safe injection facility would be to violate section 7 rights on "life, liberty and security of the person," as well as contravene the "principles of fundamental justice" ${ }^{43}$ set out in the Charter of Rights. Although falling outside the scope of the division of powers, it is interesting nevertheless to note that "the Court will not hesitate to bring Charter arguments to the fore where the recently stabilized and clarified rules of cooperative federalism cannot produce a satisfactory solution" ${ }^{\prime 4}$. This development also speaks to the incongruity of open federalism under Prime Minister Harper. To attempt to resurface idyllic notions of exclusivity within the constitution is to conveniently and willfully ignore the fact that the constitution and the

\footnotetext{
${ }^{41}$ Canadian Western Bank v. Alberta, [2007] 2 S.C.R.

3, 2007 SCC 22. See also Oliver, "Canadian Legal Federalism since 1982," p. 5-6.

${ }^{42}$ Canada (Attorney General) v. PHS Community Services Society, 2011 SCC 44, [2011] 3 S.C.R., par. 70.

43 Ibid., par. 94 and 107.

${ }^{44}$ Oliver, "Canadian Legal Federalism since 1982," p. 7.
} 
society in which it operates has changed since 1867. Governments of the twenty-first century must recognize the "continued intermingling of government roles and jurisdictions as a functional necessity in the future ${ }^{\prime 45}$. In a context whereby the division of powers has benefitted from clarifications in various legal doctrines, and where the Charter can provide another means of protection for Canadians and their provincial governments, the Supreme Court is poised to face the challenges of the impacts of the ill-fated concept of "open federalism" with a wide range of tools at its disposal.

The Supreme Court, under the direction of Chief Justice McLachlin, has clearly committed to a vision of cooperative federalism that has developed over a century of jurisprudence on the division of powers. In contrast, the federal Conservatives have presented an unclear federal vision, the product of a definitive disconnect between their theoretical policy and its operationalization. The Conservative Party, nevertheless, continues to extol their success on federalism, pointing to things such as the potential for greater innovation in health care $^{46}$, or the economic opportunities it offers to individual provinces in energy and natural resources ${ }^{47}$. Certainly, in some respects the government has been effective in moving towards greater decentralization, a debate on its merits being the matter for another study. However, it would be a stretch to suggest that decentralization necessarily equates to a successful

${ }^{45}$ Bickerton, "Deconstructing the New Federalism," p. 67.

${ }^{46}$ Conservative Party of Canada, "Balanced and Sustainable Investment in Health Care," December 21, 2011, http://www.conservative.ca/press/news_releases/b alanced_and_sustainable_investment_in_health_car e.

${ }^{47}$ Conservative Party of Canada, "Economic Action Plan 2012," March 29, 2012, http://www.conservative.ca/press/news_releases/e conomic_action_plan_2012. implementation of open federalism. The federalism which the Harper Conservatives proposes is one which is outdated and ill-fitted to meet the challenges of the twenty-first century, rooted in an impractical conception of the constitution as one which can be easily separated into convenient spheres. Despite the decline of cases dealing with the division of powers, the Supreme Court, for its part, has ensured that cooperative federalism remains a fundamental guiding element in its deliberations, ensuring the concept's survival in a new age of federal politics.

\section{Judging the Future of the Supreme Court: The Case for Renewed Leadership}

The question remains of where these developments leave the Supreme Court, particularly when facing the upcoming challenges since the third victory of the Conservative Party, garnering them their longawaited majority government. Without the compromising element inherent in the government's minority situation in the past five years, the government's legislative agenda has taken a bolder and more aggressive form, exacerbating the impact of a philosophy of "open federalism" which has promoted more discord than harmony. An investigation into the elements of this agenda and its reaction in the provinces suggests that the Supreme Court will face a substantial challenge in reconciling multiple and very different positions. Therefore, it is incumbent for us to ask: how will the Supreme Court respond to the politicized nature of these legislative conflicts, and what does this mean for not only the future of the judiciary, but the future of Canada's federal framework?

Three key pieces of legislation introduced in the $41^{\text {st }}$ Parliament provides a key point of departure, particularly since all three are hotly contested by a number of provinces and have found themselves wound up in the judicial system. From the opposition on the federal omnibus crime bill, the elimination of 
the gun registry, and the Senate elections proposal, it is argued that the government agenda serves to aggravate regional tensions in the Canadian federation which have remained relatively dormant since the turn of the century $^{48}$. In this respect, cooperative federalism has been ignored, as the Conservative government adamantly adopts a unilateralist approach to intergovernmental relations.

Bill C-10, officially referred to as the Safe Streets and Communities Act but known derisively as the omnibus crime bill by its critics, is an amalgamation of a number of initiatives brought forward by the government in its previous minority governments. It includes provisions for mandatory minimum sentencing and harsher sentences for young offenders, among others ${ }^{49}$. There is no doubt that the government holds the constitutional right to legislate on matters of criminal law ${ }^{50}$. However, given that the administration of justice is a provincial responsibility under section $92(14)^{51}$, the brunt of the costs will fall on provincial governments already strapped by limited budgetary funds in a time of fiscal austerity. The provinces of Ontario and Québec in particular have refused to shoulder these costs, calling on the government to provide the necessary funds needed to enforce the plethora of provisions contained within the bill ${ }^{52}$. Moreover, the

\footnotetext{
${ }^{48}$ Smithey, "The Effects of the Canadian Supreme Court's Charter Interpretation on Regional and Intergovernmental Relations in Canada," p. 83.

${ }^{49}$ Bill C-10, An Act to enact the Justice for Victims of Terrorism Act and to amend the State Immunity Act, the Criminal Code, the Controlled Drugs and Substances Act, the Corrections and Conditional Release Act, the Youth Criminal Justice Act, the Immigration and Refugee Protection Act and other Acts, $1^{\text {st }}$ session, $41^{\text {st }}$ Parliament, 2011.

${ }^{50}$ The Constitution Act, 1867 (UK), 30 \& 31 Victoria, c 3, s. 91(27).

${ }^{51}$ Ibid., s. 92(14).

52 The Canadian Press, “Quebec, Ontario won't pay costs of federal crime bill," Nov. 1, 2011, http://www.ctv.ca/CTVNews/TopStories/20111101/
}

government of Québec recently announced its intention to circumvent a number of its provisions, where Minister of Justice Fournier has said "he will issue a directive to various players in the justice system to avoid applying the strictest provisions of the crime bill" ${ }^{23}$. While the constitutional validity of these actions may be questionable, it illustrates how far the breakdown of the federal-provincial relationship has progressed when provinces threaten to shirk their constitutional responsibilities in the face of an unreceptive federal government.

It is clear that the government's law and order agenda, which include the mandatory minimum sentences in Bill $\mathrm{C}-10$ but also the elimination of the long-gun registry in Bill C-19 have elicited a vigorous response from the central provinces. However, the court system has also reacted to the legislative changes brought forward by the Harper government. In a judgment for the case R. v. Smickle, Ontario Superior Court judge Anne Molloy found that the application of mandatory minimum sentence provisions "would constitute cruel and unusual punishment within the meaning of s. 12 of the Charter" ${ }^{\prime 54}$. Although the matter was determined in provincial jurisdiction and in a limited context, we must admit the consequences of the legislation may yet manifest itself on future legal action on Charter grounds. If the Insite case is any indication, the Supreme Court will not hesitate in using the Charter as a means of maintaining the effective balance in Canadian federalism.

\footnotetext{
quebec-justice-minister-jean-marc-fournier-saysprovince-wont-pay-costs-of-new-federal-crime-bill111101/

${ }^{53}$ Andy Blatchford, "Omnibus crime bill: Quebec vows to circumvent new federal crime bill," The Canadian Press, March 13, 2012, http://www.thestar.com/news/canada/politics/articl e/1145322--omnibus-crime-bill-quebec-vows-tocircumvent-new-federal-crime-bill

${ }^{54}$ R. v. Smickle, [2012] ONSC 602, par. 79.
} 
The long-gun registry was also brought to court in Québec, in the case of Québec (Procureur général) c. Canada (Procureur général). The federal government's decision to eliminate gun registry records, irrespective of provincial desires to maintain these records, was challenged and the Québec government succeeded in obtaining an injunction, the court finding a fundamental dilemma at the heart of the issue:

Deux gouvernements, tous deux démocratiquement élus, proposent une vision diamétralement opposée de ce qu'il convient d'appeler le bien commun. A l'évidence, le remède recherché par le Québec mènera à la négation de la volonté du Canada, alors que la volonté de ce dernier prive le Québec, selon cette dernière, de la possibilité de mettre en oeuvre un registre québécois des armes à feu englobant les armes d'épaule réellement efficace et à jour. ${ }^{55}$

Indeed, the Québec Superior Court's reasoning can be extrapolated to the crisis at the heart of the new federalism of the century. The difficulty in reconciling the wills of democratically elected governments, both at the federal level and the provincial level, falls within the domain of the courts who act as arbiters. The failure to resolve conflicts through a basic medium of dialogue, however, threatens to debilitate the judicial system through increased litigation which places players in a zero-sum game.

Finally, the quagmire of Senate reform was revived in the parliamentary session with Bill C-7, which seeks to establish a voluntary system of Senate elections ${ }^{56}$. But as the Honourable Stéphane Dion recalls, "the

${ }^{55}$ Québec (Procureur général) c. Canada (Procureur général), [2012] QCCS 1614, par. 22.

${ }^{56}$ Bill C-7, An Act respecting the selection of senators and amending the Constitution Act, 1867, in respect of Senate term limits, $1^{\text {st }}$ session, $41^{\text {st }}$ Parliament, 2011.
Supreme Court of Canada said in 1980 that Parliament cannot alone, without the provinces, alter "the essential characteristics of the Senate" ${ }^{157}$. Given the dubious constitutionality of such provisions, the government of Québec recently filed a reference motion to the Court of Appeal challenging the legislation ${ }^{58}$ and there is a strong likelihood that the Supreme Court will be called on to add clarity to the debate. The Honourable Sénateur Nolin posits that:

Les Pères de la Confédération ont ainsi organisé le compromis législatif qui allait permettre la naissance du Canada. C'est avec grande circonspection que la cour suprême acceptera de décortiquer ce compromis politique afin de reconnaître son rôle séminal ainsi que son importance organique dans le but d'analyser toute mesure législative fédérale unilatérale visant à en modifier les composantes. ${ }^{59}$

Despite federalism's relative decline in the postCharter era, the constitutional conflict on the Senate underscores how long-standing issues continue to fester within Canadian federalism.

The common thread connecting these bills is that they reflect substantial social, demographic, and political changes that have accompanied the return of federalism to Canadian politics. With the changing political economy of the nation and the shifting balance of power to the west, the difficulties in

\footnotetext{
57 The Honourable Stéphane Dion, "Senate reform bill a recipe for grievance, gridlock," The Chronicle Herald, March 24, 2012, http://thechronicleherald.ca/opinion/77028-senatereform-bill-recipe-grievance-gridlock.

${ }^{58}$ Gouvernement du Québec, "Projet de loi C-7 sur la réforme du Sénat - Le gouvernement du Québec conteste la validité de la loi fédérale devant les tribunaux," May 1, 2012, http://communiques.gouv.qc.ca/gouvqc/communiq ues/GPQF/Mai2012/01/c2855.html?slang=en

${ }^{59}$ The Honourable Pierre-Claude Nolin, interview by Marjun Parcasio, Senate of Canada, May 3, 2012.
} 
reconciling provinces will only continue to grow $^{60}$. In the crime bill, the long-gun registry, and the Senate reform proposals, the positions of western provinces such as Alberta and British Columbia have diverged from the traditional powers of the federation located in central Canada: Ontario and Québec. The government's legislative agenda only serves to foster this regional divide, exploiting the weaknesses within the fabric of Canadian federalism. Stephen Harper and the Conservative Party are thus engaging in the politics of fragmentation and it seems to be working. The results of the 2011 federal election indicate that governing the country can be achieved without the support of Quebec, relying on the solidarity of the Western provinces as a base for popular support ${ }^{61}$. With the return of federalism, therefore, we will undoubtedly see the Québec conundrum resurface, and intergovernmental concerns continuing to rise in the face of an obstinate government in Ottawa.

The repercussions of this dangerous form of politics will be acutely felt by the Supreme Court of Canada. In the absence of firm political leadership and the lack of coherent vision for federalism by the federal government, the court must necessarily remain steadfast in its promotion of cooperative federalism. However, the politicized nature of these conflicts places the court in a delicate balancing position. Since the advent of the Charter, the dangers of the "judicialization of politics" have been widely discussed in the literature, with commentators arguing that the regime of individual rights serves to circumvent the will of democratically elected

\footnotetext{
${ }^{60}$ Joe Friesen and Bill Curry, "Canada's future is in the West: 2011 census," The Globe and Mail, February 8, 2012, http://www.theglobeandmail.com/news/national/ca nadas-future-is-in-the-west-2011census/article2330716/.

${ }^{61}$ Elections Canada, "Map of Canada - Official Results of the $41^{\text {st }}$ General Election," 2011, http://www.elections.ca/enr/help/map_41ge2.pdf.
}

governments ${ }^{62}$. As alluded to by the Quebec Superior Court in Procureur général (Québec) c. Procureur général (Canada), the attempt to reconcile competing visions of democratic governments in their interpretation of the division of powers also poses a similar and significant challenge which must be confronted $^{63}$.

As a result of the position of the Supreme Court, we can argue that the theory of judicial independence typically associated with the courts in liberal democratic systems is more a theoretical construct than a pragmatic reality ${ }^{64}$. While this certainly does not mean to suggest that the court has failed to maintain a necessary distance from actors in the political sphere, it does recognize that modern society does require the court to play multiple roles. Beyond its role as an arbiter, the Supreme Court, in advancing a separate vision of federalism different from the one proposed by the federal government, also plays the role of a facilitator and an enabler to operationalize this vision through its judgments. It is in this regard that Kelly and Murphy have characterized the court as a "meta-political actor" wherein the "management of Canada's federal constitutional architecture is a responsibility the courts share with key political actors" ${ }^{\prime 65}$. It must do so, they argue, in such a way that it provides minimal, if any, impediment to political actors but nonetheless provides the foundation upon which political actions can be taken ${ }^{66}$.

How best, then, to reconcile this seemingly paradoxical position? The Supreme

\footnotetext{
${ }^{62}$ Smithey, "The Effects of the Canadian Supreme Court's Charter Interpretation on Regional and Intergovernmental Tensions in Canada," p. 87. ${ }^{63}$ Québec (Procureur général) c. Canada (Procureur général), [2012] QCCS 1614, par. 22.

${ }^{64}$ Bzedra, "Comparative Analysis of Federal High Courts: A Political Theory of Judicial Review," p. 3. 65 James B. Kelly and Michael Murphy, "Shaping the Constitutional Dialogue on Federalism: Canada's Supreme Court as Meta-Political Actor," p. 217. ${ }^{66}$ Ibid., p. 241.
} 
Court, surely, cannot be political in its push for cooperative federalism, while at the same time apolitical in its role as an arbiter in contemporary society. The necessity to resolve this conflict is one which the Chief and Puisne Justices of the court are well-aware. It is in their seminal judgment in Canadian Western Bank that a reconciliation of these elements was expounded upon:

The [constitutional] doctrines [developed by the courts] must also be designed to reconcile the legitimate diversity of regional experimentation with the need for national unity [and] they must include a recognition that the task of maintaining the balance of powers in practice falls primarily to governments, and constitutional doctrine must facilitate, not undermine what this Court has called "cooperative federalism" ${ }^{67}$

As such, the position of the courts is solidified based on historical precedent and legal jurisprudence. Irrespective of the ideological values of the government, the court ensures its relevance in a new era of federalism. It will continue to recognize a Canada built on two levels of government, and thus any disregard for the other partner in the federal arrangement will be decried and reprimanded. It is this concept of Canada which has existed since 1867, and will continue to endure throughout the length of the twenty-first century.

It is a sad day in Canada when Canadian citizens have to look towards the courts for leadership, rather than their elected officials. In a federal country, the responsibility of the federal government lies on fostering unity and bringing the stakeholders of the federal union together at the same table. Given the contradictory nature of open federalism under the Harper government, and its tendency to sow the seeds of division amongst the provincial and territorial entities, the Supreme Court has endeavoured to reconcile these political differences. But because of the distance the court must place itself vis-à-vis the realm of politics, the real push must necessarily come from the federal government. If the Conservatives truly wish to present themselves as a federalist party, and one which will be a sustainable and viable alternative in the years to come, they must abandon their blind adherence to ideology and commit to dialogue with the provinces. Only then will cooperative federalism be truly achieved in Canadian society.

The Supreme Court, as evidenced by its balanced approach in applying legal doctrines and jurisprudence, has taken a primarily role in advancing cooperation amongst the central and subnational units of Canada's federation. But true leadership cannot originate from the nine seats at 301 Wellington. It must be founded on an attitude of collaboration by political leaders in Victoria, Edmonton, Toronto, and Québec, among others. Most importantly, the decision by the leaders of its institutional neighbour down the street at 1 Wellington to foster, rather than sever, relationships with the provinces will undoubtedly shape the future and direction for federalism in Canada.

${ }^{67}$ Canadian Western Bank v. Alberta, [2007] 2 S.C.R.

3, 2007 SCC 22, par. 24. 


\section{Bibliography}

Bickerton, James. "Deconstructing the New Federalism." Canadian Political Science Review 4:2-3 (2010), p. 56-72.

Bill C-7, An Act respecting the selection of senators and amending the Constitution Act, 1867 in respect of Senate term limits, $1^{\text {st }}$ session, $41^{\text {st }}$ Parliament, 2011.

Bill C-10, An Act to enact the Justice for Victims of Terrorism Act and to amend the State Immunity Act, the Criminal Code, the Controlled Drugs and Substances Act, the Corrections and Conditional Release Act, the Youth Criminal Justice Act, the Immigration and Refugee Protection, $1^{\text {st }}$ session, $41^{\text {st }}$ Parliament, 2011.

Bill C-19, An Act to Amend the Criminal Code and Firearms Act, $1^{\text {st }}$ session, $41^{\text {st }}$ Parliament, 2011.

Blatchford, Andy. "Omnibus crime bill: Quebec vows to circumvent new federal crime bill." The Canadian Press. March 13, 2012. http://www.thestar.com/news/canada/politics/article/1145322--omnibus-crime-bill-quebecvows-to-circumvent-new-federal-crime-bill.

Bzdera, André. "Comparative Analysis of Federal High Courts: A Political Theory of Judicial Review." Canadian Journal of Political Science 26 (1993), p. 3-29.

Canada (Attorney General) v. PHS Community Services Society, 2011 SCC 44, [2011] 3 S.C.R. 134.

Canadian Western Bank v. Alberta, [2007] 2 S.C.R. 3, 2007 SCC 22.

Conservative Party of Canada. "Balanced and Sustainable Investment in Health Care." December 21, 2011.

http://www.conservative.ca/press/news_releases/balanced_and_sustainable_investment_in_h ealth_care.

Conservative Party of Canada. “Economic Action Plan 2012." March 29, 2012.

http://www.conservative.ca/press/news_releases/economic_action_plan_2012.

Conservative Party of Canada. "Here for Canada: Stephen Harper's Low-Tax Plan for Jobs and Growth." 2011. http://www.conservative.ca/media/ConservativePlatform2011_ENs.pdf.

Conservative Party of Canada. "Stand Up for Canada: Conservative Party of Canada Federal Election Platform." 2006. http://www.cbc.ca/canadavotes2006/leadersparties/pdf/conservative_platform20060113.pdf. 
Conservative Party of Canada. "The True North Strong and Free: Stephen Harper's plan for Canadians." 2008. http://www.conservative.ca/media/2008-Platform-e.pdf.

DiGiacorno, Gord. "Take-away lessons from the SCOC's decision on the Securities Act." iPolitics.ca. March 22, 2012. http://www.ipolitics.ca/2012/03/22/gord-digiacomo-securities-act-decisionnot-helpful-to-canada/.

Elections Canada. "Map of Canada - Official Results of the $41^{\text {st }}$ General Election.” 2011. http://www.elections.ca/enr/help/map_41ge2.pdf.

Friesen, Joe and Bill Curry. "Canada's future is in the West: 2011 census." The Globe and Mail. February 8, 2012. http://www.theglobeandmail.com/news/national/canadas-future-is-in-the-west-2011census/article2330716/.

General Motors of Canada Ltd. v. City National Leasing, [1989] 1 S.C.R. 641.

Gouvernement du Québec. "Projet de loi C-7 sur la réforme du Sénat - Le gouvernement du Québec conteste la validité de la loi fédérale devant les tribunaux." May 1, 2012. http://communiques.gouv.qc.ca/gouvqc/communiques/GPQF/Mai2012/01/c2855.html?slang=e n.

Harmes, Adam. "The Political Economy of Open Federalism." Canadian Journal of Political Science 40:2 (2007), p. 1-21.

Harper, Stephen. “My Plan for Open Federalism.” National Post. A19. October 27, 2004. http://www.jamesmoore.org/harperpostoct27.htm.

Kelly, James B. and Michael Murphy. "Shaping the Constitutional Dialogue on Federalism: Canada's Supreme Court as Meta-Political Actor." Publius 35:2 (2005), p. 217-243.

Leclair, Jean. "The Supreme Court's Understanding of Federalism: Efficiency at the Expense of Diversity." Queen's Law Journal 28 (2003), p. 411-453. https://papyrus.bib.umontreal.ca/jspui/handle/1866/1431.

MacKay, Wayne A. "The Supreme Court of Canada and Federalism - Does \Should Anyone Care Anymore." Canadian Bar Review 80 (2011), p. 241-280.

Monahan, Patrick. Constitutional Law, $3^{\text {rd }}$ ed. Toronto: Irwin Law, 2006.

Multiple Access Ltd. v. McCutcheon, [1982] 2 S.C.R. 161. 
Oliver, Peter C. "The Busy Harbours of Canadian Federalism: The Division of Powers and Its Doctrines in the McLachlin Court." In Public Law at the McLachlin Court: The First Decade, edited by David A. Wright and Adam M. Dodek, 167-200. Toronto: Irwin Law, 2011.

Prime Minister of Canada, "Prime Minister promotes open federalism," Apr. 21, 2006, http://pm.gc.ca/eng/media.asp?id=1123.

Québec (Procureur général) c. Canada (Procureur général), [2012] QCCS 1614

R. v. Smickle, [2012] ONSC 602.

Reference re Secession of Quebec, [1998] 2 S.C.R. 217.

Reference re Securities Act, [2011] SCC 66.

Smithey, Shannon Ishiyama. "The Effects of the Canadian Supreme Court's Charter Interpretation on Regional and Intergovernmental Tensions in Canada." Publius 26:2 (1996), p. 83-100.

Swinton, Katherine. "Federalism under Fire: The Role of the Supreme Court of Canada." Law and Contemporary Problems 55:1 (1992), p. 121-145.

The Canadian Press. "Quebec, Ontario won't pay costs of federal crime bill." Nov. 1, 2011. http://www.ctv.ca/CTVNews/TopStories/20111101/quebec-justice-minister-jean-marc-fourniersays-province-wont-pay-costs-of-new-federal-crime-bill-111101/.

The Constitution Act, 1867 (UK), 30 \& 31 Victoria, c 3.

The Honourable Hugh Segal. Interview by Marjun Parcasio. Senate of Canada. May 1, 2012.

The Honourable Pierre-Claude Nolin. Interview by Marjun Parcasio. Senate of Canada. May 3, 2012.

The Honourable Stéphane Dion. "Senate reform bill a recipe for grievance, gridlock." The Chronicle Herald. March 24, 2012. http://thechronicleherald.ca/opinion/77028-senate-reform-bill-recipegrievance-gridlock 